Article

\title{
Antiviral Effects of ABMA against Herpes Simplex Virus Type 2 In Vitro and In Vivo
}

\author{
Wenwen Dai ${ }^{1}$, Yu Wu ${ }^{2}$, Jinpeng Bi ${ }^{1}$, Shuai Wang ${ }^{1}$, Fang Li ${ }^{1}$, Wei Kong 1,3, \\ Julien Barbier $^{2}$ (D), Jean-Christophe Cintrat ${ }^{2}$, Feng Gao ${ }^{1,3}$, Daniel Gillet ${ }^{2, *(D)}$, \\ Weiheng Su ${ }^{1,3, *}$ and Chunlai Jiang ${ }^{1,3, *}$ \\ 1 National Engineering Laboratory for AIDS Vaccine, School of Life Sciences, Jilin University, \\ Changchun 130012, Jilin, China; daiwenwen92@163.com (W.D.); 15143080402@163.com (Ji.B.); \\ a1251892522@163.com (S.W.); li296981502@126.com (F.L.); weikong@jlu.edu.cn (W.K.); \\ feng0215@gmail.com (F.G.) \\ 2 SIMOPRO, CEA, Université Paris-Saclay, F-91191 Gif Sur Yvette, France; wuyu81@gmail.com (Y.W.); \\ Julien.BARBIER@cea.fr (Ju.B.); jean-christophe.cintrat@cea.fr (J.-C.C.) \\ 3 Key Laboratory for Molecular Enzymology and Engineering of the Ministry of Education, \\ School of Life Sciences, Jilin University, Changchun 130012, Jilin, China \\ * Correspondence: daniel.gillet@cea.fr (D.G.); suweiheng@jlu.edu.cn (W.S.); jiangcl@jlu.edu.cn (C.J.); \\ Tel.: +33-(0)1-69-08-76-46 (D.G.); +86-0431-8516-7751 (W.S. \& C.J.)
}

Received: 27 January 2018; Accepted: 8 March 2018; Published: 9 March 2018

\begin{abstract}
Herpes simplex virus type 2 (HSV-2) is the causative pathogen of genital herpes and is closely associated with the occurrence of cervical cancer and human immunodeficiency virus (HIV) infection. The absence of an effective vaccine and the emergence of drug resistance to commonly used nucleoside analogs emphasize the urgent need for alternative antivirals against HSV-2. Recently, ABMA [1-adamantyl (5-bromo-2-methoxybenzyl) amine] has been demonstrated to be an inhibitor of several pathogens exploiting host-vesicle transport, which also participates in the HSV-2 lifecycle. Here, we showed that ABMA inhibited HSV-2-induced cytopathic effects and plaque formation with $50 \%$ effective concentrations of 1.66 and $1.08 \mu \mathrm{M}$, respectively. We also preliminarily demonstrated in a time of compound addition assay that ABMA exerted a dual antiviral mechanism by impairing virus entry, as well as the late stages of the HSV-2 lifecycle. Furthermore, in vivo studies showed that ABMA protected BALB/c mice from intravaginal HSV-2 challenge with an improved survival rate of $50 \%$ at $5 \mathrm{mg} / \mathrm{kg}$ ( $8.33 \%$ for the untreated virus infected control). Consequently, our study has identified ABMA as an effective inhibitor of HSV-2, both in vitro and in vivo, for the first time and presents an alternative to nucleoside analogs for HSV-2 infection treatment.
\end{abstract}

Keywords: herpes simplex virus type 2; ABMA; antiviral effect; entry; late stage; vesicle transport

\section{Introduction}

Genital herpes is one of the world's most prevalent sexually transmitted diseases [1], and manifests as ulcerative and vesicular lesions on the genitals with lifelong latency [2]. Herpes simplex virus type 2 (HSV-2) — a single, large double-stranded DNA, enveloped virus belonging to the Herpesviridae family-is the major cause of genital herpes [3], and significantly increases the risk of developing cervical cancer and human immunodeficiency virus (HIV) infection [4-6]. HSV-2 infection is a global concern with estimates of 536 million people infected worldwide and an annual incidence of 23.6 million cases [7].

Despite the prevalence of infection in the global population, no vaccine has been developed and antiviral chemotherapy is standard practice in the management of HSV-2 infection [8,9]. However, long-term therapy with acyclovir and penciclovir as well as their prodrugs valaciclovir and famciclovir, respectively, has led to the emergence of drug resistance, especially in immune-compromised 
patients [10]. Additionally, various cases of toxicity have been encountered as a result of increasing use of traditional antivirals [11,12]. Although some non-nucleoside inhibitors have been developed, few are currently approved for HSV-2 infection treatment [13]. Foscarnet is approved as a second-line drug for HSV-2 infection treatment only when the patient has failed first-line treatment with acyclovir or there is a proven resistance mutation, and the use of foscarnet is limited by its toxicity and the fact that it is available only as an intravenous formulation [14]. Therefore, alternative antivirals against HSV-2 are needed.

The small molecule ABMA [1-adamantyl (5-bromo-2-methoxybenzyl) amine], was first identified from a cell-based high throughput screening, as an inhibitor of ricin, both in cell cultures and in mice, selectively acting on host-endosomal trafficking [15]. Subsequently, ABMA has been reported to be active against other infectious pathogens, including bacterial toxins (diphtheria toxin from Corynebacterium diphtheriae, lethal toxin from Bacillus anthracis, toxin B from Clostridium difficile and lethal toxin from Clostridium sordellii), viruses (Ebola virus, Rabies virus and Dengue-4 virus), bacteria (Simkaniaceae and Chlamydiaceae) and Leishmania parasite [15]. Each of these pathogens relies on host-endosomal trafficking for pathogenicity, indicating that the inhibitory effect of ABMA is related to host-vesicle transport [16-18].

HSV-2 initiates infection with attachment to host cells, followed by membrane fusion or endocytosis to enter the cells. Subsequently, de-enveloped tegument-capsids are transported to the nuclei, where genome transcription, DNA replication and new capsid assembly occur. Filled capsids then bud into vesicles derived from the trans-Golgi network to obtain an envelope and an outer membrane after release from the nuclei. Finally, viruses exit the host cells by fusion of enveloped virus-containing vesicles with the cell membranes. Several processes including endocytic virus entry, virus capsid envelopment and virus egress in the HSV-2 lifecycle depend on host-vesicle transport, providing a rationale for testing ABMA as an inhibitor of HSV-2.

In this study, we evaluated the antiviral activity of ABMA against HSV-2, in vitro and in vivo, and provided data to address possible mechanisms of action. Chloroquine, which was reported to inhibit herpes simplex virus infection by interacting with endocytic virus entry and the late stages of infection, as well as acyclovir, which is commonly used as the drug for HSV-2 infection treatment, were chosen as positive control drugs in this study [19-24]. ABMA was demonstrated to be an effective inhibitor of HSV-2 by a dual mechanism of action, acting on virus entry as well as the late stages of infection.

\section{Materials and Methods}

\subsection{Cells, Virus, Compounds and Mice}

African green monkey kidney cells (Vero cells) obtained from American type culture collection (ATCC) (cat \# CCL-81) were cultured in Dulbecco's modified Eagle's medium (DMEM, Invitrogen, Carlsbad, CA, USA) supplemented with 10\% fetal bovine serum (FBS, Invitrogen) (DMEM-10\% FBS) at $37{ }^{\circ} \mathrm{C}$ with $5 \% \mathrm{CO}_{2}$.

HSV-2 strain G obtained from ATCC (cat \# VR-734) (KU310668) was propagated in Vero cells. Virus titration was performed by endpoint dilution and plaque assays.

ABMA [1-adamantyl (5-bromo-2-methoxybenzyl) amine] (Figure 1) was synthesized in-house. The positive control drugs, chloroquine and acyclovir, were purchased from Meilun Biotech Co., Ltd. (Dalian, China) [19-24]. The purities of the compounds were higher than $98 \%$, as determined by High Performance Liquid Chromatography (HPLC). The compounds were dissolved in dimethyl sulfoxide (DMSO) as stock solutions.

Specific-pathogen-free female BALB/c mice (6-8 weeks old) were obtained from the Changchun Institute of Biological Products and maintained under the guidelines for animal experiments at Jilin University, China. 


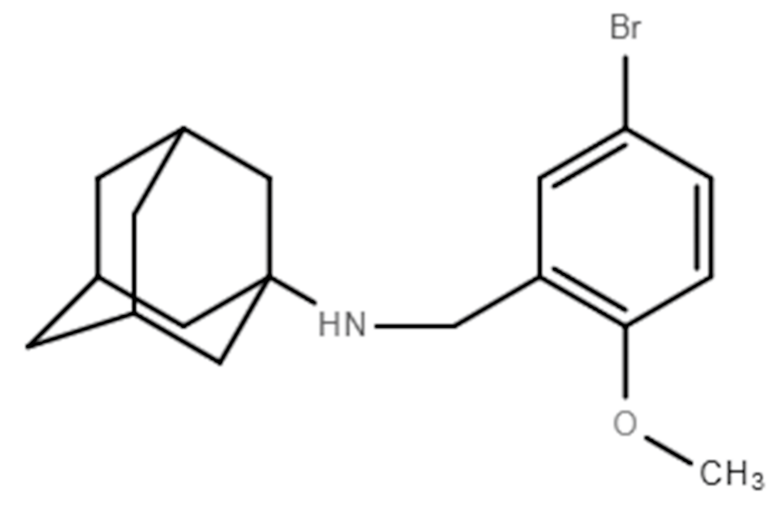

Figure 1. Chemical structure of ABMA.

\subsection{Cytotoxicity Assay}

Cytotoxicity was measured by the Cell Titer-Glo ${ }^{\circledR}$ Luminescent cell viability assay, as reported previously [25]. Serially diluted compounds were added to $90 \%$ confluent Vero cells in 96-well plates. After incubation for $72 \mathrm{~h}$, cell viability was assayed with the Cell Titer-Glo ${ }^{\circledR}$ reagent (Promega, Madison, WI, USA) and quantified by the PerkinElmer VICTORTM X2 (Waltham, MA, USA). Cytotoxicity was measured by the percentage of the luminescence intensity of compound-treated cells relative to that of the untreated cell control. The $50 \%$ cytotoxicity concentration $\left(\mathrm{CC}_{50}\right)$ was calculated by regression analysis of the dose-response curves [26].

\subsection{Antiviral Activity Assay of ABMA against HSV-2 In Vitro}

The antiviral activity of ABMA against HSV-2 was measured by cytopathic effect (CPE) inhibition and plaque reduction assays. In the CPE inhibition assay, serially diluted ABMA or chloroquine (positive control drug), was added to $90 \%$ confluent Vero cells in 96-well plates $5 \mathrm{~h}$ before infection with HSV-2 (MOI $=0.04$, which was determined to cause appropriate CPE $(100 \%)$ and cell viability reduction $(60 \%)$ on Vero cells after infection for $72 \mathrm{~h}$ ), while acyclovir (positive control drug) was added at the same time as infection. After incubation for $72 \mathrm{~h}$ post-infection in the presence of the compounds, cell viability was measured as described in Section 2.2.

In the plaque reduction assay, serially diluted ABMA or chloroquine (positive control drug), was added to Vero cell monolayers in 12-well plates $5 \mathrm{~h}$ before infection with HSV-2 (50-100 PFU, which was determined to ensure that appropriate numbers of plaques form in the plates and are counted accurately), while acyclovir (positive control drug) was added at the same time as infection. After infection for $1 \mathrm{~h}$, DMEM-2\% FBS-1\% low-melting agarose containing the above compounds at corresponding concentrations was overlaid in place of infected medium. Plaque numbers were counted after the cells were fixed with $4 \%$ paraformaldehyde and stained with $0.5 \%$ crystal violet when plaques formed.

CPE inhibition and plaque reduction rates were measured by the following equations: CPE inhibition $(\%)=(\mathrm{T}-\mathrm{V}) /(\mathrm{C}-\mathrm{V}) \times 100 \%$, where $\mathrm{C}, \mathrm{V}$ and $\mathrm{T}$ are the luminescence intensities of the untreated cell control, the untreated virus infected control and compound-treated cells, respectively. Plaque reduction $(\%)=\left[1-(\text { plaque number })_{\mathrm{T}} /(\text { plaque number })_{\mathrm{V}}\right] \times 100 \%$, where $(\text { plaque number })_{\mathrm{T}}$ and $(\text { plaque number })_{\mathrm{V}}$ are plaque numbers of compound-treated cells and the untreated virus-infected control, respectively. The $50 \%$ effective concentration $\left(\mathrm{EC}_{50}\right)$, which refers to the concentration of a drug that induces a response halfway between the baseline and the maximum after a specified exposure time, was calculated by regression analysis of the dose-response curves [26]. 


\subsection{Western Blotting}

Cell samples were lysed in RIPA buffer (Beyotime Biotech Co., Ltd., Shanghai, China) and the lysates were cleaned by centrifugation at $12,000 \mathrm{rpm}$. The proteins were separated by SDS-PAGE and transferred onto nitrocellulose membranes. After being blocked with $3 \%$ non-fat milk for $1 \mathrm{~h}$, the membranes were incubated with an anti-HSV-2 VP5 (major capsid protein of HSV-2 [27]) mouse monoclonal antibody (EastCoast Bio, North Berwick, ME, USA) or an anti- $\beta$-tubulin mouse monoclonal antibody (Covance, Emeryville, CA, USA) for $2 \mathrm{~h}$. Blots were subsequently incubated with an alkaline phosphatase (AP)-conjugated anti-mouse IgG antibody (SouthernBiotech, Birmingham, AL, USA) for $1 \mathrm{~h}$ and developed by the interaction between AP and AP substrates, followed by termination with the exposure to light.

\subsection{Quantitative Polymerase Chain Reaction ( $q P C R)$ Assay}

The Ezup Column Virus DNA Purification Kit (Sangon Biotech Co., Ltd., Shanghai, China) was used to extract HSV-2 DNA. TransStart ${ }^{\circledR}$ Top Green qPCR SuperMix (TransGen Biotech Co., Ltd., Beijing, China) and gG specific primers (forward primer: 5'-CCCACACCCCAACACATC-3', reverse primer: $5^{\prime}$-CCAAGGCGACCAGACAAAC- $3^{\prime}$ ) were used for amplification and subsequent quantification with the Bio-Rad CFX96 system (Hercules, CA, USA).

\subsection{Time of ABMA Addition Assay}

In the antiviral activity assay against HSV-2 based on the measurement of viral protein and DNA content in the cell cultures, $3.13 \mu \mathrm{M}$ ABMA or $15 \mu \mathrm{M}$ chloroquine was added to $90 \%$ confluent Vero cells in 24-well plates $5 \mathrm{~h}$ before infection with HSV-2 (MOI $=1$, which was determined to ensure synchronized infection in a single replicative lifecycle as reported [28]), while $1 \mu \mathrm{M}$ acyclovir was added at the same time as infection. After infection for $1 \mathrm{~h}$, DMEM-2\% FBS containing the above compounds at their corresponding concentrations was overlaid in place of the medium. Proteins and HSV-2 DNA were extracted and quantified as described in Sections 2.4 and 2.5 at $18 \mathrm{~h}$ post-infection, when a single lifecycle had been completed without the occurrence of obvious CPE [29].

In the effective stage assay, ABMA $(3.13 \mu \mathrm{M})$ and HSV-2 (MOI $=1)$ were added to $90 \%$ confluent Vero cells in 24-well plates following different treatment schemes, as reported with some modifications [29]. To study a prophylactic effect (pre: $-5-0 \mathrm{~h}$ ), the cells were pretreated with ABMA for $5 \mathrm{~h}$, then infected with HSV-2 after removal of ABMA by washing. To study an inhibitory effect on virus binding or entry (simultaneous: $0-1 \mathrm{~h}$ ), the cells were treated with ABMA and infected with HSV-2 at the same time, then overlaid with DMEM-2\% FBS after removal of the medium by washing at $1 \mathrm{~h}$ post-infection. To study the effect on virus replication (early post: $1-6 \mathrm{~h}$ ), the infected cells were treated with ABMA from $1 \mathrm{~h}$ to $6 \mathrm{~h}$ post-infection, then overlaid with DMEM- $\%$ FBS after removal of ABMA by washing. To study the effect on late stage infection (late post: 6-18 h), the infected cells were cultured with DMEM-2\% FBS for $5 \mathrm{~h}$, then treated with ABMA from $6 \mathrm{~h}$ to $18 \mathrm{~h}$ post-infection. Besides, HSV-2 was pre-incubated with ABMA at $4{ }^{\circ} \mathrm{C}$ for $5 \mathrm{~h}$ before infection (direct) to study the direct interactions in a cell free system. HSV-2 infection was performed during $0-1 \mathrm{~h}$ for all procedures, except for direct procedure, in which the cells were infected with HSV-2 that had been pretreated with ABMA. HSV-2 DNA in the cell cultures was extracted and quantified as described in Section 2.5 at $18 \mathrm{~h}$ post-infection.

\subsection{Binding and Entry Assays}

Binding and entry assays were performed as reported previously, with some modifications [30]. The $90 \%$ confluent Vero cells in 24-well plates were pretreated with $3.13 \mu \mathrm{M}$ ABMA, $15 \mu \mathrm{M}$ chloroquine or $1 \mu \mathrm{M}$ acyclovir for $5 \mathrm{~h}$ before addition of HSV-2. In the binding assay, the cells were exposed to HSV-2 $(\mathrm{MOI}=1)$ at $4{ }^{\circ} \mathrm{C}$ for $2 \mathrm{~h}$. Unbound viruses were removed by washing twice with sterile PBS buffer 
at $4{ }^{\circ} \mathrm{C}$, and HSV-2 DNA from the original virus inoculum and the unbound virus supernatant were extracted separately and quantified as described in Section 2.5 to calculate the amount of bound HSV-2.

In the entry assay, the cells were further incubated at $37^{\circ} \mathrm{C}$ for $1 \mathrm{~h}$ after the binding process. After two freeze-thaw cycles of the infected cells, HSV-2 DNA from the internalized virus was extracted and quantified to calculate the amount of HSV-2 that was able to enter the cells.

\subsection{Late Stage Infection Assay}

To study the effects of ABMA on the late stages of the HSV-2 lifecycle, $90 \%$ confluent Vero cells in 24-well plates were infected with HSV-2 (MOI = 1) for $1 \mathrm{~h}$, then treated with $3.13 \mu \mathrm{M}$ ABMA, $15 \mu \mathrm{M}$ chloroquine or $1 \mu \mathrm{M}$ acyclovir during 6-18 h post-infection. At $18 \mathrm{~h}$ post-infection, the supernatants and the infected cells were collected and subjected to direct extracellular virus titration and to intracellular virus titration after two freeze-thaw cycles. Virus titers were determined by the Reed and Muench dilution method and expressed as $50 \%$ tissue culture infectious doses per milliliter $\left(\mathrm{TCID}_{50} / \mathrm{mL}\right)$.

\subsection{Antiviral Efficacy Assay of ABMA against HSV-2 In Vivo}

Female BALB/c mice (6-8 weeks old, $n=10-12$ per group) were injected subcutaneously with $2 \mathrm{mg}$ of Depo-Provera (XianJu Pharmaceutical Co., Ltd., Taizhou, China) per mouse to induce a diestrus phase in the genital tract. Seven days later, the mice were inoculated intravaginally with 50,000 PFU of HSV-2 in $10 \mu \mathrm{L}$ of PBS after anesthesia. At $1 \mathrm{~h}$ post-inoculation, and subsequently once daily for seven consecutive days, $1.25 \mathrm{mg} / \mathrm{kg}$ or $5 \mathrm{mg} / \mathrm{kg}$ of ABMA (the doses were determined to ensure sufficient dissolution of ABMA in the injections), or $150 \mathrm{mg} / \mathrm{kg}$ of acyclovir (positive control) [31] was administered intraperitoneally. The compounds were all dissolved in PBS supplemented with 10\% DMSO and PBS supplemented with 10\% DMSO was administered as an untreated virus infected control. The mice were monitored daily for survival rate and clinical score. Signs of disease were evaluated as: 0 , healthy; 1 , genital erythema; 2, moderate genital inflammation; 3, genital lesion; 4, hind-limb paralysis; 5, death [32]. Vaginal swab samples were collected at day 5 and day 10 and transferred to $200 \mu \mathrm{L}$ of Hank's buffer. HSV-2 titers from the swab samples were determined by plaque assay in Vero cells as reported [33]. Protocols for animal experiments were approved by the Committee on Animal Experimental Ethics of School of Life Sciences at Jilin University [permission code: 2017-nsfc019, 15 January 2017].

\subsection{Statistical Analysis}

In vitro experiments were conducted in technical triplicate and repeated three times independently. A one-way ANOVA test was used for statistical analysis to compare the differences between test groups and untreated virus infected control groups. A log-rank test (Mantel-Cox) was used for comparisons of the survival curves. Statistical significance is represented by asterisks and was marked correspondingly in the figures $\left({ }^{*} p<0.05,{ }^{* *} p<0.01,{ }^{* * *} p<0.001\right)$.

\section{Results}

\subsection{Reductions of HSV-2-Induced Cytopathic Effects and Plaque Formation Were Detected in ABMA-Treated Cells}

ABMA was tested for cytotoxicity before assessing its antiviral activity. As shown in Figure 2A and Table 1, Vero cells responded to ABMA in a dose-dependent manner with a $\mathrm{CC}_{50}$ value of $34.75 \mu \mathrm{M}$. No cytotoxicity was observed at the concentrations effective against HSV-2 infection. It is current practice in drug discovery processes to pretreat cells with the compound before infection, in order to better monitor a positive effect. ABMA was tested for anti-HSV-2 activity with treatment administered from $5 \mathrm{~h}$ before infection to the end of the assays, as reported previously [15]. As shown in Figure 2B and Table 1, ABMA inhibited HSV-2-induced CPE in a dose-dependent manner with an EC 50 value of $1.66 \mu \mathrm{M}$ and a maximum inhibition rate of $93.36 \%$ at $3.13 \mu \mathrm{M}$. The selective index (SI) measuring 
the safety of a compound to be developed as an antiviral agent was calculated to be 20.93 by $\mathrm{CC}_{50}$ relative to $\mathrm{EC}_{50}$ [34], which was higher than that of the positive control drug, chloroquine. A plaque reduction assay was performed subsequently to confirm the anti-HSV-2 activity. As shown in Figure 2C and Table 1, ABMA inhibited HSV-2-induced plaque formation in a dose-dependent manner with an $\mathrm{EC}_{50}$ value of $1.08 \mu \mathrm{M}$, which was in accordance with the results obtained in the CPE inhibition assay. Morphological changes of the cells also confirmed the protective effects of ABMA against HSV-2 infection. As shown in Figure 3, untreated virus-infected cells appeared all rounded up and detached from the plates, uninfected cells looked all spread out, while virus infected cells treated with the drugs were mostly spread out and partially rounded up. Thus, ABMA is a safe and effective antiviral agent against HSV-2 in vitro, which protects cells from HSV-2 infection below its toxic concentration.
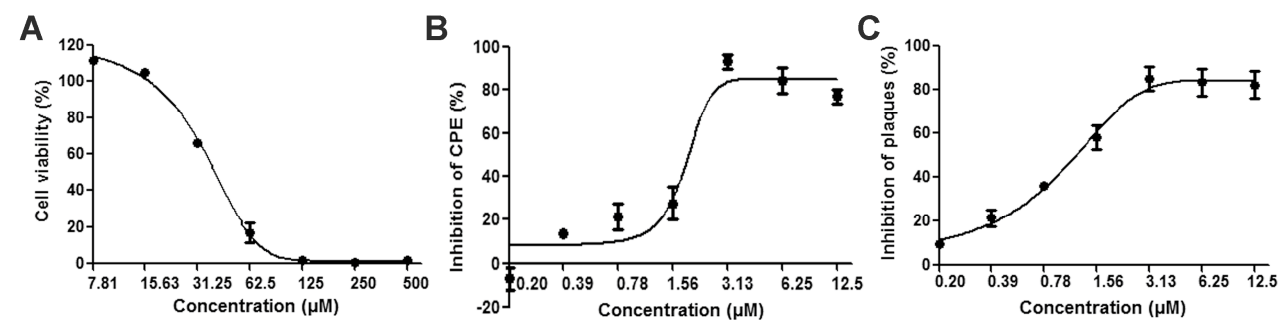

Figure 2. Cytotoxicity and antiviral activity of ABMA against HSV-2 in vitro. (A) Serially diluted ABMA was added to Vero cells, then cell viability was measured and compared to that of the untreated cell control after incubation for $72 \mathrm{~h}$. (B) Serially diluted ABMA was added to Vero cells $5 \mathrm{~h}$ before infection with HSV-2 (MOI = 0.04), then cell viability was measured to calculate the CPE inhibition percentage after infection for $72 \mathrm{~h}$ in the presence of ABMA. (C) Serially diluted ABMA was added to Vero cells $5 \mathrm{~h}$ before infection with HSV-2 (50-100 PFU) for $1 \mathrm{~h}$, then DMEM-2\% FBS- $1 \%$ low-melting agarose containing ABMA at corresponding concentrations was overlaid in place of infected medium, followed by counting of plaque numbers to calculate the plaque inhibition percentage when plaques formed.

Table 1. Cytotoxicity and antiviral activity of compound against HSV-2 in Vero cells.

\begin{tabular}{ccccc}
\hline & Cytotoxicity & \multicolumn{3}{c}{ Antiviral Activity } \\
\hline Compounds & $\mathrm{CC}_{\mathbf{5 0}}(\boldsymbol{\mu M})$ & $\mathrm{EC}_{\mathbf{5 0}}{ }^{\mathbf{a}}(\boldsymbol{\mu M})$ & $\mathbf{E C}_{\mathbf{5 0}}{ }^{\mathbf{b}}(\boldsymbol{\mu M})$ & $\mathbf{S I}^{\mathbf{c}}$ \\
\hline ABMA & $34.75 \pm 0.28$ & $1.66 \pm 0.14$ & $1.08 \pm 0.25$ & 20.93 \\
Chloroquine & $15.67 \pm 0.47$ & $1.86 \pm 0.20$ & $1.38 \pm 0.03$ & 8.42 \\
Acyclovir & $>1000$ & $0.82 \pm 0.06$ & $0.81 \pm 0.07$ & 1219.51 \\
\hline
\end{tabular}

${ }^{a}$ Concentration at which the compound CPE inhibition rate reaches halfway between the baseline and the maximum; ${ }^{b}$ concentration at which the compound plaque reduction rate reaches halfway between the baseline and the maximum; ${ }^{c}$ selective index (SI) value represents the ratio of $\mathrm{CC}_{50} / \mathrm{EC}_{50}{ }^{\mathrm{a}}$ for each compound; Results are presented as mean values \pm standard deviations (SD) obtained from three independent experiments.

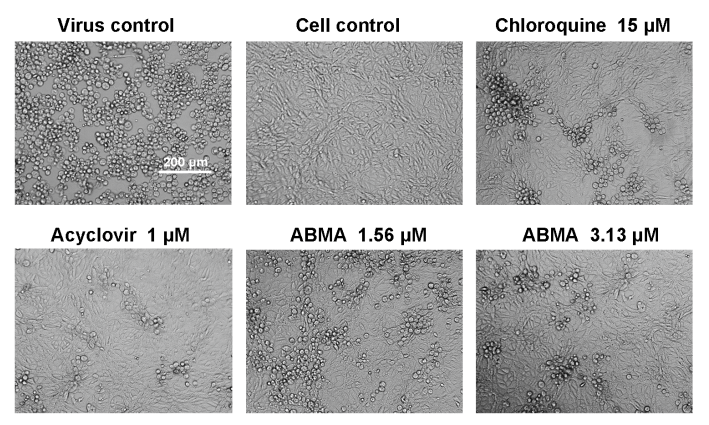

Figure 3. Effects of compounds on HSV-2-induced CPE. Morphological changes of Vero cells were recorded by phase-contrast microscopy at $72 \mathrm{~h}$ post-infection following the CPE inhibition assay. Virus control and cell control represented untreated virus infected cells and uninfected cells, respectively. Scale bar $=200 \mu \mathrm{m}$. 


\subsection{Reductions of HSV-2 Protein and DNA Content Were Detected in ABMA-Treated Cells}

The effects of ABMA on HSV-2 proliferation were measured by quantifying HSV-2 protein and DNA content in the cell cultures. ABMA treatment was administered from $5 \mathrm{~h}$ prior to infection, through to the end of the assays. HSV-2 protein and DNA content were assayed by Western blot and qPCR assays, respectively, after a single replicative cycle, before the occurrence of obvious CPE at $18 \mathrm{~h}$ post-infection [29]. As shown in Figure 4A, a significant reduction in the content of HSV-2 VP5 (main capsid protein of HSV-2 [27]) was observed in ABMA-treated cells, while that of $\beta$-tubulin (constitutive protein essential for cell function) was not affected. As shown in Figure 4B, a significant reduction in HSV-2 DNA content was also detected in ABMA-treated cells. The positive control drugs, chloroquine and acyclovir reduced HSV-2 protein synthesis and DNA replication as expected [19-24]. Based on those data, ABMA appears to be an effective antiviral agent against HSV-2 in vitro, which can cause reduced HSV-2 protein and DNA content in the cell cultures.

A

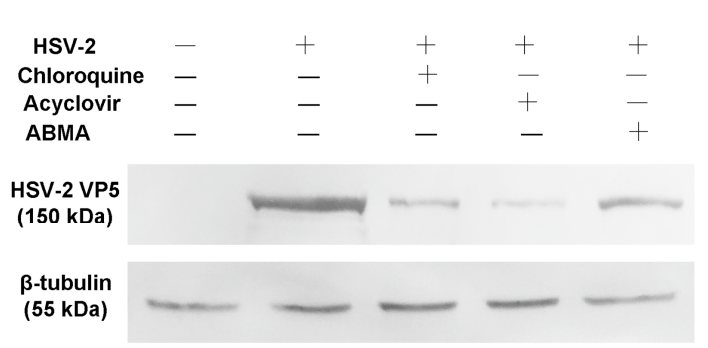

B

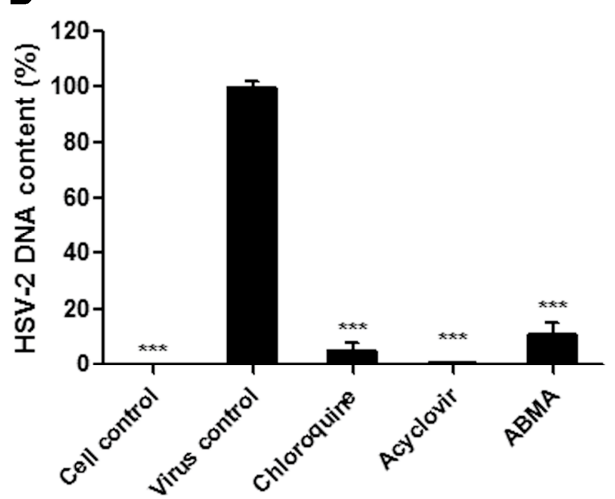

Figure 4. Effects of compounds on HSV-2 protein and DNA content in cell cultures. $3.13 \mu \mathrm{M}$ ABMA or $15 \mu \mathrm{M}$ chloroquine was added to Vero cells $5 \mathrm{~h}$ before infection with HSV-2 (MOI =1), while $1 \mu \mathrm{M}$ acyclovir was added at the same time as infection. Then DMEM-2\% FBS containing the compounds at their corresponding concentrations was overlaid in place of the medium after infection for $1 \mathrm{~h}$. (A) Proteins were extracted from the cell cultures at $18 \mathrm{~h}$ post-infection, then separated by SDS-PAGE and analyzed by Western blot using an anti-HSV-2 VP5 antibody or an anti- $\beta$-tubulin antibody. " + " and "-" represented "with" and "without" the additions, respectively. (B) HSV-2 DNA was extracted from the cell cultures at $18 \mathrm{~h}$ post-infection and quantified by qPCR. Statistical significance was compared between test groups and the untreated virus infected control group and was represented by asterisks marked in the figures, where ${ }^{* * *} p<0.001$.

\subsection{ABMA Blocks HSV-2 Entry into Cells}

The effects of ABMA on different stages of the HSV-2 lifecycle were measured by a mode of action assay following different ABMA treatment schemes (Figure 5A). ABMA was added at time points corresponding to different events in the HSV-2 lifecycle. HSV-2 DNA content in the cell cultures for all assay conditions were measured at $18 \mathrm{~h}$ post-infection. Significant reductions in HSV-2 DNA content were detected when the cells were pre-treated with ABMA prior to infection (pre), or when ABMA was introduced from 6-18 $\mathrm{h}$ post-infection (late post) (Figure $5 \mathrm{~B}$ ). The results strongly suggested that ABMA affected the early events in the HSV-2 lifecycle by acting on the cells directly. ABMA also had an effect on the late stages of the HSV-2 lifecycle as a result of treatment during 6-18 h post-infection (Figure 5B). As there was no loss in cell viability at the concentration of ABMA used in the experiments $(3.13 \mu \mathrm{M})$ (Figure 2A), the inhibitory effects of ABMA were not due to cytotoxicity. Therefore, ABMA affects both early and late stages of the HSV-2 lifecycle. The latter mechanism was discussed further in Section 3.4. 
A

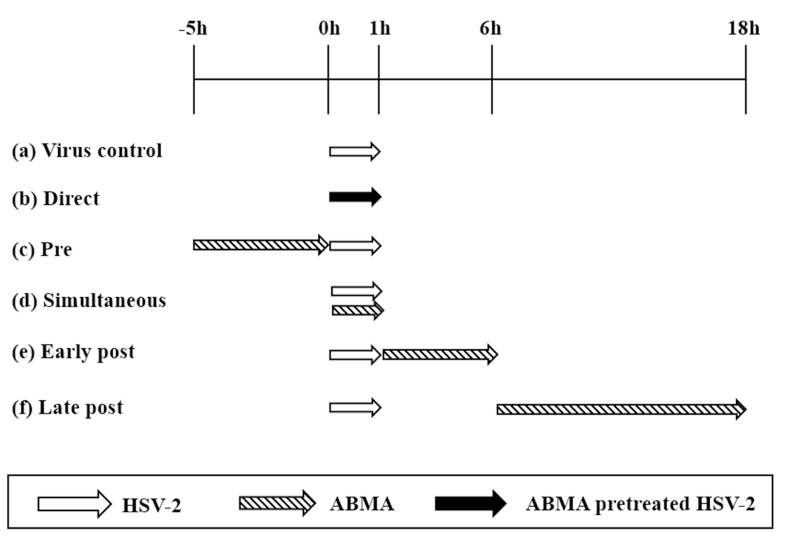

B

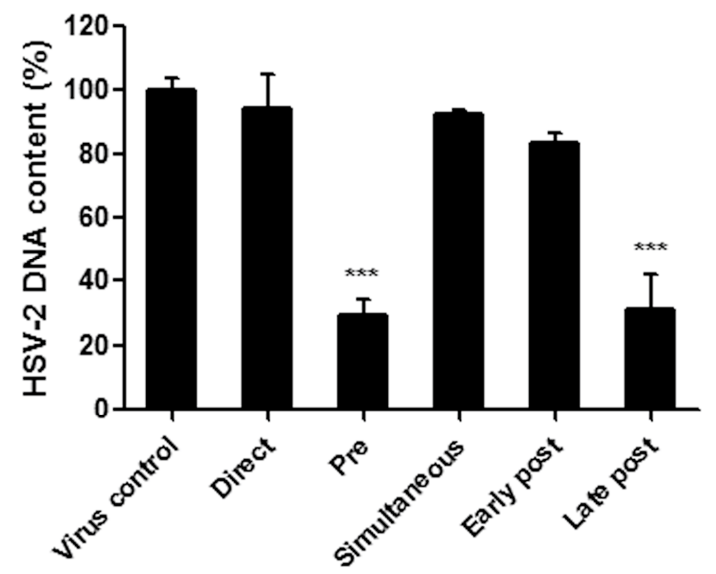

Figure 5. Effects of ABMA on different stages of the HSV-2 lifecycle. (A) ABMA $(3.13 \mu \mathrm{M})$ treatment and HSV-2 (MOI = 1) infection schemes in the time of ABMA addition assay. (B) HSV-2 DNA was extracted from the cell cultures at $18 \mathrm{~h}$ post-infection following the treatment schemes in (A) and quantified by qPCR. Statistical significance was compared between test groups and the untreated virus infected control group and was represented by asterisks marked in the figures, where ${ }^{* * *} p<0.001$.

As antiviral agents targeting the essential early stages of the HSV-2 lifecycle (binding and entry) may be more effective than those targeting the late stages, events in the early stages of the HSV-2 lifecycle that could be targeted by ABMA were further investigated [35]. HSV-2 binding and entry assays were performed at $4{ }^{\circ} \mathrm{C}$ and $37{ }^{\circ} \mathrm{C}$, respectively, after pretreatment of the cells with the compounds. This was followed by quantification of bound and entered viruses by measuring HSV-2 DNA content in the original virus inoculum, the unbound virus supernatant from the binding assay (unbound virus) and the internalized virus after freeze-thaw cycles of the infected cells from the entry assay (entered virus), respectively (Figure 6A). As shown in Figure 6B,C, HSV-2 entry was significantly reduced by ABMA, similarly to chloroquine, which is known to affect HSV-2 entry $[20,21,24]$. As expected, acyclovir that blocks virus replication had no effect on virus binding or entry [19]. Therefore, ABMA blocks HSV-2 entry into cells.

A

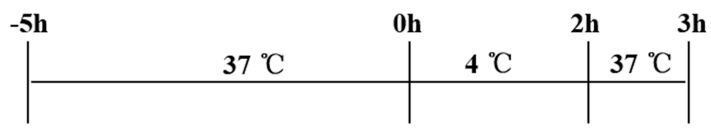

(a) Binding

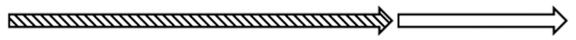

(b) Entry
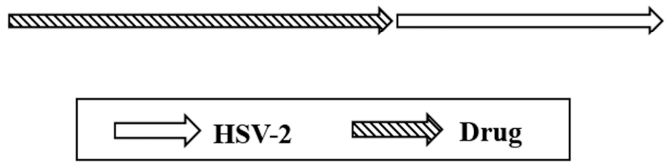

Figure 6. Cont. 


\section{B}

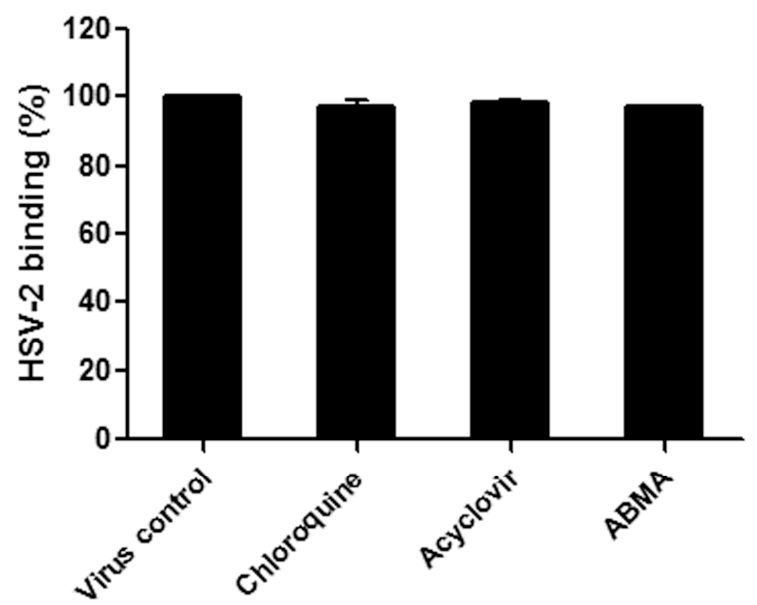

C

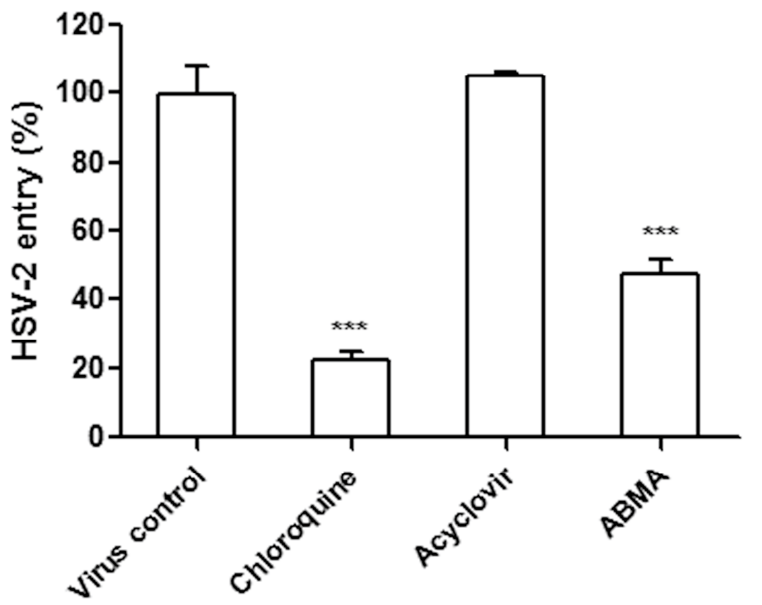

Figure 6. Effects of compounds on HSV-2 binding and entry. (A) Drug treatment and HSV-2 (MOI = 1) incubation schemes in binding and entry assays. (B) HSV-2 DNA was extracted from the original virus inoculum and unbound virus supernatant at $2 \mathrm{~h}$ post-incubation of the cells with HSV-2 at $4{ }^{\circ} \mathrm{C}$ and quantified to calculate the amount of HSV-2 bound to the cells in the binding assay. (C) HSV-2 DNA was extracted from the internalized virus after two freeze-thaw cycles of the infected cells at $1 \mathrm{~h}$ post-infection with HSV-2 at $37^{\circ} \mathrm{C}$ following the binding process and quantified to calculate the amount of HSV-2 that was internalized in cells in the entry assay. Statistical significance was compared between test groups and the untreated virus infected control group and was represented by asterisks marked in the figures, where ${ }^{* * *} p<0.001$.

\subsection{ABMA Inhibits the Late Stages of the HSV-2 Lifecycle}

The effects of ABMA on the late stages of the HSV-2 lifecycle were further studied using the late stage infection assay at $18 \mathrm{~h}$ post-infection. HSV-2-infected cells were treated with the compounds during $6-18 \mathrm{~h}$ post-infection, which corresponds to the late stages of the HSV-2 lifecycle. Following this, intracellular and extracellular virus titers were measured (Figure 7A). As shown in Figure 7B, both intracellular and extracellular HSV-2 titers were significantly reduced by ABMA. As chloroquine was reported to interact with the late stages of the HSV lifecycle, virus titers were significantly reduced, as expected $[20,22,23]$. As the target of acyclovir was demonstrated to be HSV-2 DNA replication, which mainly takes place during 3-6 h post-infection, virus titers were reduced to a lesser extent [19]. These results confirmed the inhibitory effects of ABMA on the late stages of the HSV-2 lifecycle, as described in Section 3.3. Additionally, these results also suggested that the HSV-2 packaging and egress process was most likely to be blocked by ABMA, as capsid formation and progeny infectious particle packaging gradually take place from $5 \mathrm{~h}$ post-infection onwards [36]. 
A
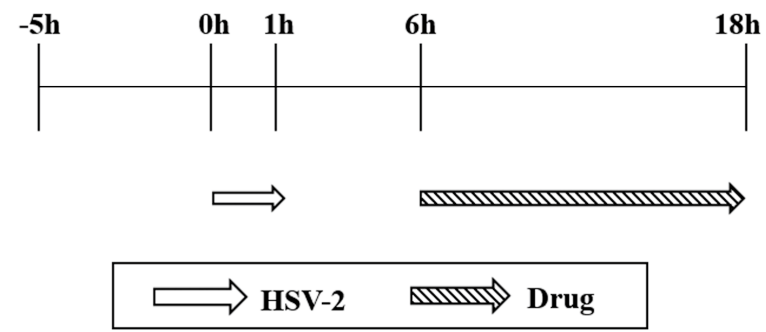

B

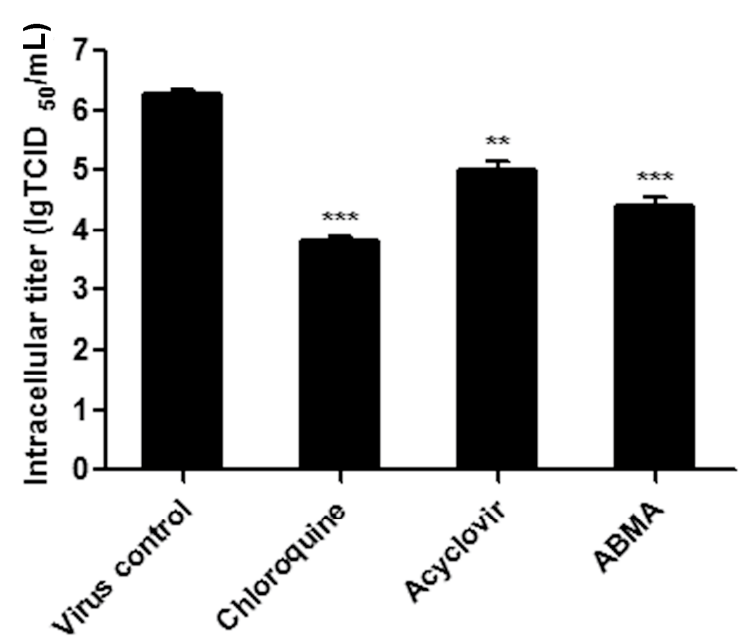

C

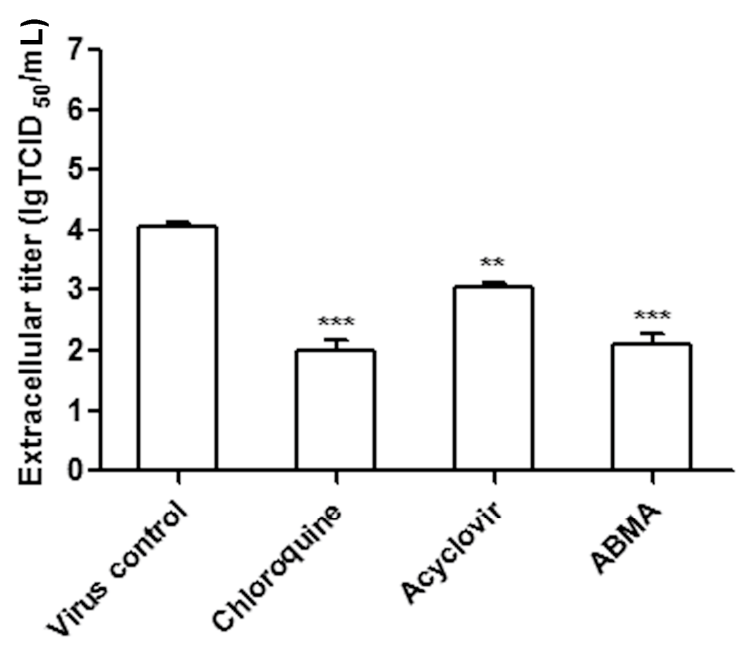

Figure 7. Effects of compounds on the late stages of the HSV-2 lifecycle. (A) Drug treatment and HSV-2 $(\mathrm{MOI}=1)$ incubation schemes in the late stage infection assay. (B) Intracellular viruses were collected from the infected cells after two freeze-thaw cycles at $18 \mathrm{~h}$ post-infection following the treatment schemes in (A) and subjected to virus titration. (C) Extracellular viruses were collected from the cell supernatants at $18 \mathrm{~h}$ post-infection following the treatment schemes in (A) and subjected to virus titration. Statistical significance was compared between test groups and the untreated virus infected control groups and was represented by asterisks marked in the figures, where ${ }^{* *} p<0.01,{ }^{* * *} p<0.001$.

\subsection{ABMA Protects BALB/c Mice from Intravaginal HSV-2 Challenge}

Having identified the anti-HSV-2 potency of ABMA in vitro, we next evaluated the protective efficacy of ABMA against intravaginal challenge of HSV-2 in BALB/c mice using a reported mouse model [37]. As shown in Figure 8A, ABMA significantly improved the survival rates of drug-treated infected mice compared to the untreated virus infected control, whose survival rate was $8.33 \%$. ABMA given daily intraperitoneally at $5 \mathrm{mg} / \mathrm{kg}$ provided the best survival rate of $50 \%$. As shown in Figure 8B, ABMA at both doses tested reduced the clinical score in the same trend as the survival rate. Mice treated with $5 \mathrm{mg} / \mathrm{kg}$ of ABMA showed the lowest clinical score, below 3, while the value of the untreated virus infected control reached 4.58. Several mice with clinical score below 2 (moderate genital inflammation) recovered from the infection along with time. However, mice with clinical score higher than 2 did not recover. As clinical scores in Figure $8 \mathrm{~B}$ were presented as the mean value of 10-12 mice, there was no reduction in clinical scores along with time as a result. Despite that, ABMA significantly reduced the severity of the disease and slowed the progress time course of mice compared to the untreated virus infected mice. As acyclovir is normally used as the standard treatment of HSV-2 infection, it was used as the positive control drug in the in vivo experiment [31]. The protective rate of acyclovir at $150 \mathrm{mg} / \mathrm{kg}$ was shown to be $100 \%$, as expected [31]. Body weight changes of mice were also recorded over 20 days, but there was no significant difference among these groups (data no shown). HSV-2 titers from the vaginal swabs at day 5, when viral load 
reached its peak, and at day 10, for a later time point, were also detected to confirm the protective efficacy of ABMA against HSV-2 infection in vivo [38]. As shown in Figure 8C, HSV-2 was detected in all groups indicating a successful HSV-2 challenge. ABMA at $5 \mathrm{mg} / \mathrm{kg}$ significantly reduced HSV-2 titers by $0.55 \mathrm{log}$ and $0.60 \log$ at day 5 and day 10, respectively. Acyclovir at $150 \mathrm{mg} / \mathrm{kg}$ significantly reduced HSV-2 titers by $0.97 \log$ and $1.20 \log$ at day 5 and day 10, respectively. Based on these data, ABMA effectively protects $\mathrm{BALB} / \mathrm{c}$ mice from intravaginal HSV-2 challenge.

Overall, ABMA is an effective antiviral agent against HSV-2 in vitro and in vivo, with two putative modes of action, affecting both virus entry and the late stages of the HSV-2 lifecycle.
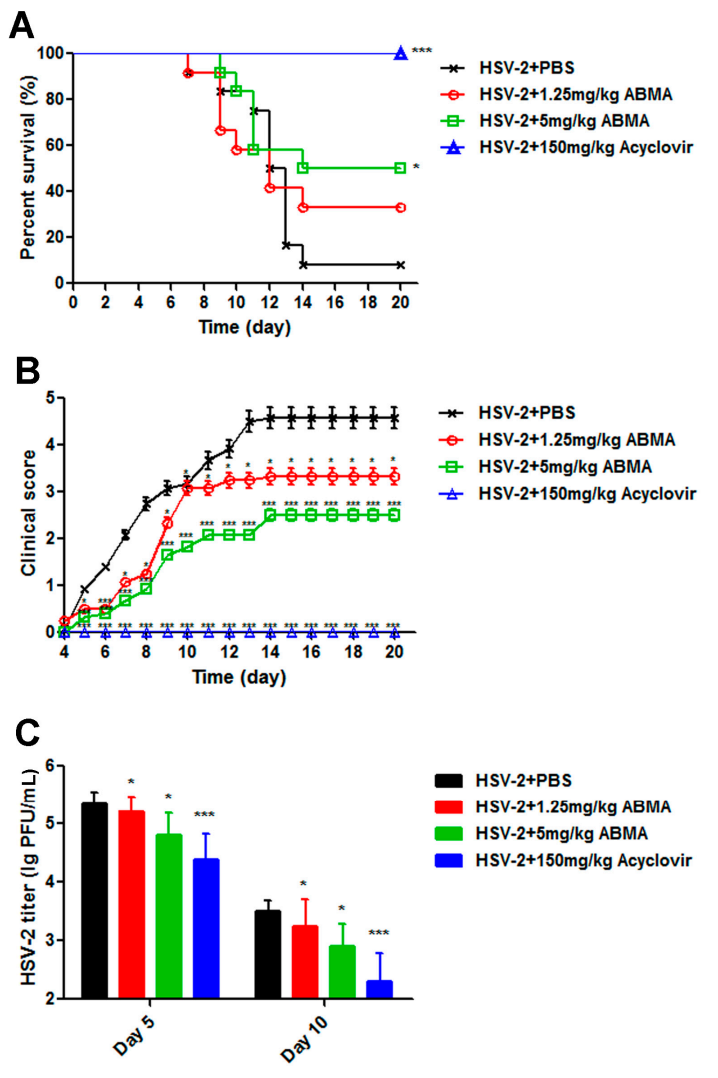

Figure 8. Antiviral efficacy of ABMA against intravaginal HSV-2 challenge in BALB/c mice. Female BALB/c mice (6-8 weeks old, $n=10-12$ per group) were injected subcutaneously with $2 \mathrm{mg}$ of Depo-Provera per mouse seven days before intravaginal inoculation with 50,000 PFU of HSV-2 in $10 \mu \mathrm{L}$ of PBS. At $1 \mathrm{~h}$ post-inoculation and once daily for seven consecutive days, $1.25 \mathrm{mg} / \mathrm{kg}$ or $5 \mathrm{mg} / \mathrm{kg}$ of ABMA, $150 \mathrm{mg} / \mathrm{kg}$ of acyclovir, or PBS supplemented with $10 \%$ DMSO was administered intraperitoneally. (A) Survival rate and (B) clinical score of the mice were monitored daily for 20 days. (C) Vaginal swab samples were collected at day 5 and day 10, respectively, and transferred to $200 \mu \mathrm{L}$ of Hank's buffer, followed by virus titer determination by plaque assay in Vero cells. Statistical significance was compared between test groups and the untreated virus infected control and was represented by asterisks marked in the figures, where ${ }^{*} p<0.05,{ }^{* * *} p<0.001$.

\section{Discussion}

The prevalence, severity of complications and the close association with cervical cancer and HIV infection make HSV-2 infection a global health concern [39]. The lack of an available vaccine and the emergence of drug resistance highlight the importance of developing alternative antivirals against HSV-2 with distinct modes of action [10]. ABMA has been demonstrated previously to be active against several intracellular pathogens exploiting host-vesicle transport [15]. Here we demonstrated that ABMA is an effective inhibitor of HSV-2, in vitro and in vivo. 
The anti-HSV-2 potential of ABMA was first identified in vitro with $\mathrm{EC}_{50}$ values below $2 \mu \mathrm{M}$ and an SI value of 20.93, which is suitable for an antiviral agent [40] (Figure 2 and Table 1). Treatment with ABMA also resulted in significant reductions of HSV-2 protein and DNA content in the cell cultures (Figure 4). Subsequently, ABMA was found to target both early and late stages of the HSV-2 lifecycle in the time of compound addition assay, which was similar to the effects of SPL-2999 (a dendrimer with the active surface group of naphthyl 3,6-disulfonic acid sodium salts to interact with biological surfaces) on HSV-2 [41] (Figure 5).

ABMA was found to affect the early stages of HSV-2 infection by acting on cells directly, as reported in previous studies on the effects of polysaccharide extracts from algal species and SPL-2999 on HSV-2 [41,42]. The specific event targeted by ABMA in the early stages of HSV-2 infection was found to be virus entry into cells, while binding was unaffected by ABMA treatment, which was similar to the effect of Dynasore (a small-molecule inhibitor of dynamin, which is a GTPase that controls multiple endocytic pathways and also plays a role in actin assembly and reorganization) on HSV-2 entry [30] (Figure 6). Although herpes simplex virus (HSV) may enter cells by direct fusion between the virus envelope with the cell membranes, substantial evidences for HSV entry through an endocytic-dependent mechanism have come to light [43]. HSV begins endocytic entry by using the host membrane machinery to envelop viruses. The viruses trapped in endocytic vesicles can then be released to the host cytoplasm by fusion of the virus envelope with the vesicle membranes [44]. The inhibitory effect of ABMA on HSV-2 entry might be related to its effect on host-vesicle transport [15], which is involved in the endocytic entry pathway of HSV-2. Antivirals targeting early stage infection have attracted significant attention because reduced entry of viruses into cells translates to decreased replication and spread to other cells [35]. Most early-stage prevention drugs that show promise in treating HSV-2 infection are binding inhibitors, targeting the host cell receptor or the viral glycoprotein required for binding [43,44]. Agents preventing HSV-2 entry into cells, including SPL-2999, PM-19 (a keggin-type heteropolyoxotungstate $\mathrm{K}_{7}\left[\mathrm{PTi}_{2} \mathrm{~W}_{10} \mathrm{O}_{40}\right] \cdot 6 \mathrm{H}_{2} \mathrm{O}$ ), Dynasore and ABMA reported in our study may provide alternative early stage inhibitors [30,41,45].

In addition to virus entry, ABMA was also found to inhibit the late stages of HSV-2 infection, which was confirmed by significantly reduced intracellular and extracellular virus titers when ABMA was applied during 6-18 h post-infection (Figure 7). Additionally, because HSV-2 DNA replicates rapidly between 3-6 $\mathrm{h}$ and the formation of both the capsids and the progeny infectious particles of HSV-2 gradually takes place from approximately $5 \mathrm{~h}$ post-infection onwards [36], the results also suggested that ABMA was most likely to hinder the HSV-2 packaging and egress process, as reported in a study on the effects of Nelfinavir on HSV-1 [46]. The HSV-2 packaging and egress process begins with capsid assembly in the nuclei, then infectious particles are packaged by budding the capsids into specialized vesicles derived from the trans-Golgi network to gain an envelope and an outer vesicular membrane. Finally, the virus-containing vesicles move to and fuse with the cell membranes to release the viruses into the extracellular medium [47-49]. The fact that ABMA was likely to block the HSV-2 packaging and egress process suggested two possible explanations: the target of ABMA present on host-endosomal transport is also present on the HSV-2 packaging and egress process. Alternatively, host-endosomal transport, which can be affected by ABMA, participates in the HSV-2 packaging and egress process.

Significant protective efficacy of ABMA against intravaginal HSV-2 challenge in female BALB/c mice was demonstrated by an improved survival rate, reduced clinical score and reduced vaginal virus load compared to the untreated virus infected control (Figure 8). ABMA administered at the highest tested dose of $5 \mathrm{mg} / \mathrm{kg}$ showed the best survival rate of $50 \%$, while that of the untreated virus infected control was $8.33 \%$. Several recently developed inhibitors of HSV-2 have undergone, or are currently undergoing clinical trials, but most of them have yet to gain licensure due to adverse effects on the host [13]. Based on our study, ABMA might provide an alternative. As ABMA is an initial hit from a high throughput screening, further medicinal chemistry and pharmaceutical optimizations are still required and may lead to candidates with higher anti-HSV-2 activities. 
Multi-drug therapy, combining drugs with different modes of action to limit the manifestation of drug resistance and to increase the selectivity by reduced dose, is common practice in the treatment of viral infections, including HIV and HCV (hepatitis C virus), but not HSV, for which currently available drugs have the same target, the viral DNA polymerase [50,51]. ABMA was demonstrated to be an effective inhibitor of HSV-2 with the targets of virus entry as well as the late stages of viral lifecycle, which were different from commonly used acyclovir. It might well be possible to develop combinations of ABMA with acyclovir, or other drugs targeting stages different from ABMA in the HSV-2 lifecycle, such as virus replication. These novel combinations might be more effective and might provide an alternative to HSV-2 infection treatment.

In conclusion, AMBA has been identified as an effective inhibitor of HSV-2 in vitro and in vivo, by inhibiting virus entry, as well as the late stages of the HSV-2 lifecycle. Our study expands the list of pathogens against which ABMA is active and exemplifies the potential of ABMA to be developed as a broad-spectrum inhibitor. As the target of ABMA is a host component rather than the pathogens themselves, drug resistance may be less likely to arise [52].

Acknowledgments: This work was supported by grants from Natural Science Foundation of China [grant number 31770184]; a grant from the Agence Nationale de la Recherche and the LERMIT LabEx [grant number ANR-10-LABX-33], Ile de France Region grant from the DIM Malinf initiative 140101 and CEA.

Author Contributions: Wenwen Dai, Wei Kong, Feng Gao, Daniel Gillet, Weiheng Su and Chunlai Jiang conceived and designed the experiments; Wenwen Dai, Jinpeng Bi, Shuai Wang and Fang Li performed the experiments; Yu Wu analyzed the data; Wenwen Dai, Julien Barbier and Jean-Christophe Cintrat wrote the paper. All authors listed have approved the submission.

Conflicts of Interest: The authors declare no conflict of interest.

\section{References}

1. Kawana, T. Sexually transmitted diseases of alpha herpes virus in women. Nihon Rinsho Jpn. J. Clin. Med. 2000, 58, 883-889.

2. Corey, L.; Adams, H.G.; Brown, Z.A.; Holmes, K.K. Genital herpes simplex virus infections: Clinical manifestations, course, and complications. Ann. Intern. Med. 1983, 98, 958-972. [CrossRef] [PubMed]

3. Gupta, R.; Warren, T.; Wald, A. Genital herpes. Lancet 2007, 370, 2127-2137. [CrossRef]

4. Lehtinen, M.; Koskela, P.; Jellum, E.; Bloigu, A.; Anttila, T.; Hallmans, G.; Luukkaala, T.; Thoresen, S.; Youngman, L.; Dillner, J.; et al. Herpes simplex virus and risk of cervical cancer: A longitudinal, nested case-control study in the Nordic countries. Am. J. Epidemiol. 2002, 156, 687-692. [CrossRef] [PubMed]

5. Wald, A.; Link, K. Risk of human immunodeficiency virus infection in herpes simplex virus type 2-seropositive persons: A meta-analysis. J. Infect. Dis. 2002, 185, 45-52. [CrossRef] [PubMed]

6. Celum, C.L. The interaction between herpes simplex virus and human immunodeficiency virus. Herpes J. IHMF 2004, 11 (Suppl. 1), 36A-45A.

7. Looker, K.; Magaret, A.; Turner, K.; Vickerman, P.; Gottlieb, S.; Newman, L. Global estimates of prevalent and incident herpes simplex virus type 2 infections in 2012. PLoS ONE 2015, 10, e114989. [CrossRef] [PubMed]

8. Johnston, C.; Koelle, D.M.; Wald, A. HSV-2: In pursuit of a vaccine. J. Clin. Investig. 2011, 121, 4600-4609. [CrossRef] [PubMed]

9. White, P.J.; Garnett, G.P. Use of antiviral treatment and prophylaxis is unlikely to have a major impact on the prevalence of herpes simplex virus type 2. Sex. Trans. Infect. 1999, 75, 49-54. [CrossRef]

10. Bacon, T.H.; Levin, M.J.; Leary, J.J; Sarisky, R.T.; Sutton, D. Herpes simplex virus resistance to acyclovir and penciclovir after two decades of antiviral therapy. Clin. Microbiol. Rev. 2003, 16, 114. [CrossRef] [PubMed]

11. Johnson, G.L.; Limon, L.; Trikha, G.; Wall, H. Acute renal failure and neurotoxicity following oral acyclovir. Ann. Pharm. 1994, 28, 460-463. [CrossRef] [PubMed]

12. Ernst, M.E.; Franey, R.J. Acyclovir- and ganciclovir-induced neurotoxicity. Ann. Pharm. 1998, 32, 111-113. [CrossRef] [PubMed]

13. De, S.K.; Hart, J.C.L.; Breuer, J. Herpes simplex virus and varicella zoster virus: Recent advances in therapy. Curr. Opin. Infect. Dis. 2015, 28, 589-595. [CrossRef] [PubMed] 
14. Khurana, R.N.; Charonis, A.; Samuel, M.A.; Gupta, A.; Tawansy, K.A. Intravenous foscarnet in the management of acyclovir-resistant herpes simplex virus type 2 in acute retinal necrosis in children. Med. Sci. Monit. 2005, 11, CS75-CS78. [PubMed]

15. Wu, Y.; Pons, V.; Goudet, A.; Panigai, L.; Fischer, A.; Herweg, J.-A.; Kali, S.; Davey, R.A.; Laporte, J.; Bouclier, C.; et al. ABMA, a small molecule that inhibits intracellular toxins and pathogens by interfering with late endosomal compartments. Sci. Rep. 2017, 7, 15567. [CrossRef] [PubMed]

16. Sandvig, K.; van Deurs, B. Delivery into cells: Lessons learned from plant and bacterial toxins. Gene Ther. 2005, 12, 865-872. [CrossRef] [PubMed]

17. White, J.M.; Whittaker, G.R. Fusion of Enveloped Viruses in Endosomes. Traffic 2016, 17, 593-614. [CrossRef] [PubMed]

18. Lievin-Le Moal, V.; Loiseau, P.M. Leishmania hijacking of the macrophage intracellular compartments. Febs J. 2016, 283, 598-607. [CrossRef] [PubMed]

19. Brady, R.C.; Bernstein, D.I. Treatment of herpes simplex virus infections. Antivir. Res. 2004, 61, 73-81. [CrossRef] [PubMed]

20. Savarino, A.; Boelaert, J.R.; Cassone, A.; Majori, G.; Cauda, R. Effects of chloroquine on viral infections: An old drug against today's diseases? Lancet Infect. Dis. 2003, 3, 722-727. [CrossRef]

21. Storey, N.; Latchman, D.; Bevan, S. Selective internalization of sodium channels in rat dorsal root ganglion neurons infected with herpes simplex virus-1. J. Cell Biol. 2002, 158, 1251-1262. [CrossRef] [PubMed]

22. Harley, C.A.; Dasgupta, A.; Wilson, D.W. Characterization of herpes simplex virus-containing organelles by subcellular fractionation: Role for organelle acidification in assembly of infectious particles. J. Virol. 2001, 75, 1236-1251. [CrossRef] [PubMed]

23. McClain, L.; Zhi, Y.; Cheng, H.; Ghosh, A.; Piazza, P.; Yee, M.B.; Kumar, S.; Milosevic, J.; Bloom, D.C.; Arav-Boger, R.; et al. Broad-spectrum non-nucleoside inhibitors of human herpesviruses. Antivir. Res. 2015, 121, 16-23. [CrossRef] [PubMed]

24. Lund, J.; Sato, A.; Akira, S.; Medzhitov, R.; Iwasaki, A. Toll-like receptor 9-mediated recognition of herpes simplex virus-2 by plasmacytoid dendritic cells. J. Exp. Med. 2003, 198, 513-520. [CrossRef] [PubMed]

25. Crouch, S.P.; Kozlowski, R.; Slater, K.J.; Fletcher, J. The use of ATP bioluminescence as a measure of cell proliferation and cytotoxicity. J. Immunol. Methods 1993, 160, 81-88. [CrossRef]

26. Weislow, O.S.; Kiser, R.; Fine, D.L.; Bader, J.; Shoemaker, R.H.; Boyd, M.R. New soluble-formazan assay for HIV-1 cytopathic effects: Application to high-flux screening of synthetic and natural products for AIDS-antiviral activity. J. Natl. Cancer Inst. 1989, 81, 577-586. [CrossRef] [PubMed]

27. Brown, J.C.; Newcomb, W.W. Herpesvirus capsid assembly: Insights from structural analysis. Curr. Opin. Virol. 2011, 1, 142-149. [CrossRef] [PubMed]

28. Yao, F.; Eriksson, E. Inhibition of herpes simplex virus type 2 (HSV-2) viral replication by the dominant negative mutant polypeptide of HSV-1 origin binding protein. Antivir. Res. 2002, 53, 127-133. [CrossRef]

29. Argenta, D.F.; Silva, I.T.; Bassani, V.L.; Koester, L.S.; Teixeira, H.F.; Simoes, C.M.O. Antiherpes evaluation of soybean isoflavonoids. Arch. Virol. 2015, 160, 2335-2342. [CrossRef] [PubMed]

30. Mues, M.B.; Cheshenko, N.; Wilson, D.W.; Gunther-Cummins, L.; Herold, B.C. Dynasore Disrupts Trafficking of Herpes Simplex Virus Proteins. J. Virol. 2015, 89, 6673-6684. [CrossRef] [PubMed]

31. Reefschlager, J.; Wutzler, P.; Thiel, K.D.; Herrmann, G. Efficacy of 5-vinyl-1-beta-D-arabinofuranosyluracil (VaraU) against herpes simplex virus type 2 strains in cell cultures and against experimental herpes encephalitis in mice: Comparison with acyclovir and foscarnet. Pharm. Res. 1987, 4, 200-206. [CrossRef] [PubMed]

32. Shestakov, A.; Jenssen, H.; Nordstrom, I.; Eriksson, K. Lactoferricin but not lactoferrin inhibit herpes simplex virus type 2 infection in mice. Antivir. Res. 2012, 93, 340-345. [PubMed]

33. Hong, L.; Xu, X.; Chen, L.; Li, B.; Wu, D.; Hu, M.; Sun, Q.; Zhu, X.; Wu, W.; Hong, S.; et al. The anti-HSV-2 effect of alumen: In vitro and in vivo experimental studies. J. Huazhong Univ. Sci. Technol.-Med. Sci. 2011, 31, 828-833. [CrossRef] [PubMed]

34. Cheng, H.-Y.; Yang, C.-M.; Lin, T.-C.; Lin, L.-T.; Chiang, L.-C.; Lin, C.-C. Excoecarianin, Isolated from Phyllanthus urinaria Linnea, Inhibits Herpes Simplex Virus Type 2 Infection through Inactivation of Viral Particles. Evid.-Based Complement. Altern. Med. 2011, 2011, 259103. [CrossRef] [PubMed]

35. Hadigal, S.; Shukla, D. Exploiting Herpes Simplex Virus Entry for Novel Therapeutics. Viruses 2013, 5, 1447-1465. [PubMed] 
36. Koyama, A.H.; Uchida, T. Quantitative studies on the maturation process of herpes simplex virus type 1 in Vero cells. Virus Res. 1988, 10, 281-285. [CrossRef]

37. Parr, M.B.; Kepple, L.; McDermott, M.R.; Drew, M.D.; Bozzola, J.J.; Parr, E.L. A mouse model for studies of mucosal immunity to vaginal infection by herpes simplex virus type 2. Lab. Investig. J. Tech. Methods Pathol. 1994, 70, 369-380.

38. Yin, S.; Li, Y.; Xia, H.; Zhao, J.; Zhang, Z.; Tang, S.; Kou, Z.; Chen, J.; Yu, J.; Fan, Z.; et al. An improved system for the evaluation of antiviral compounds against herpes simplex virus type 2. J. Virol. Methods 2013, 189, 317-320. [CrossRef] [PubMed]

39. Drannik, A.G.; Nag, K.; Sallenave, J.-M.; Rosenthal, K.L. Antiviral Activity of Trappin-2 and Elafin In Vitro and In Vivo against Genital Herpes. J. Virol. 2013, 87, 7526-7538. [CrossRef] [PubMed]

40. Tsuchiya, Y.; Shimizu, M.; Hiyama, Y.; Itoh, K.; Hashimoto, Y.; Nakayama, M.; Horie, T.; Morita, N. Antiviral activity of natural occurring flavonoids in vitro. Chem. Pharm. Bull. 1985, 33, 3881-3886. [CrossRef] [PubMed]

41. Gong, Y.H.; Matthews, B.; Cheung, D.; Tam, T.; Gadawski, I.; Leung, D.; Holan, G.; Raff, J.; Sacks, S. Evidence of dual sites of action of dendrimers: SPL-2999 inhibits both virus entry and late stages of herpes simplex virus replication. Antivir. Res. 2002, 55, 319-329. [CrossRef]

42. Harden, E.A.; Falshaw, R.; Carnachan, S.M.; Kern, E.R.; Prichard, M.N. Virucidal activity of polysaccharide extracts from four algal species against herpes simplex virus. Antivir. Res. 2009, 83, 282-289. [CrossRef] [PubMed]

43. Agelidis, A.M.; Shukla, D. Cell entry mechanisms of HSV: What we have learned in recent years. Future Virol. 2015, 10, 1145-1154. [CrossRef] [PubMed]

44. Akhtar, J.; Shukla, D. Viral entry mechanisms: Cellular and viral mediators of herpes simplex virus entry. Febs J. 2009, 276, 7228-7236. [CrossRef] [PubMed]

45. Dan, K.; Miyashita, K.; Seto, Y.; Fujita, H.; Yamase, T. The memory effect of heteropolyoxotungstate (PM-19) pretreatment on infection by herpes simplex virus at the penetration stage. Pharmacol. Res. 2002, 46, 357-362. [CrossRef] [PubMed]

46. Kalu, N.N.; Desai, P.J.; Shirley, C.M.; Gibson, W.; Dennis, P.A.; Ambinder, R.F. Nelfinavir Inhibits Maturation and Export of Herpes Simplex Virus 1. J. Virol. 2014, 88, 5455-5461. [CrossRef] [PubMed]

47. Owen, D.J.; Crump, C.M.; Graham, S.C. Tegument Assembly and Secondary Envelopment of Alphaherpesviruses. Viruses 2015, 7, 5084-5114. [CrossRef] [PubMed]

48. Mingo, R.M.; Han, J.; Newcomb, W.W.; Brown, J.C. Replication of Herpes Simplex Virus: Egress of Progeny Virus at Specialized Cell Membrane Sites. J. Virol. 2012, 86, 7084-7097. [CrossRef] [PubMed]

49. Granzow, H.; Klupp, B.G.; Fuchs, W.; Veits, J.; Osterrieder, N.; Mettenleiter, T.C. Egress of alphaherpesviruses: Comparative ultrastructural study. J. Virol. 2001, 75, 3675-3684. [CrossRef] [PubMed]

50. Toews, M.L.; Bylund, D.B. Pharmacologic principles for combination therapy. Proc. Am. Thorac. Soc. 2005, 2, 282-289; discussion 290-291. [CrossRef] [PubMed]

51. Andrei, G.; Snoeck, R. Herpes simplex virus drug-resistance: New mutations and insights. Curr. Opin. Infect. Dis. 2013, 26, 551-560. [CrossRef] [PubMed]

52. Bekerman, E.; Einav, S. Combating emerging viral threats. Science 2015, 348, 282-283. [CrossRef] [PubMed]

(C) 2018 by the authors. Licensee MDPI, Basel, Switzerland. This article is an open access article distributed under the terms and conditions of the Creative Commons Attribution (CC BY) license (http://creativecommons.org/licenses/by/4.0/). 